\title{
MUS81 wt Allele
}

National Cancer Institute

\section{Source}

National Cancer Institute. MUS81 wt Allele. NCI Thesaurus. Code C116616.

Human MUS81 wild-type allele is located in the vicinity of $11 q 13$ and is approximately 11 $\mathrm{kb}$ in length. This allele, which encodes crossover junction endonuclease MUS81 protein, is involved in DNA endonuclease activity. 